\title{
FACTORS AFFECTING THE WORK STRESS OF POLICE OFFICERS: A SYSTEMATIC REVIEW
}

\author{
FAKTOR-FAKTOR YANG MEMPENGARUHI STRES KERJA PETUGAS POLISI: \\ TINJAUAN SISTEMATIS
}

\author{
By : \\ Rachma Yuniar Wijayanti ${ }^{1}$ \\ Hanandita Belva Fauzi ${ }^{2}$
}

\begin{abstract}
ABSTRAK
Submitted:

26 Februari 2020

Revision:

28 Februari 2020

Accepted:

11 April 2020

Aparat kepolisian rentan mengalami stres kerja, apapun bidang atau fungsi yang mereka lakukan. Tujuan dari studi literatur ini adalah untuk mengetahui faktor-faktor yang mempengaruhi stres kerja pada petugas polisi. Jurnal yang digunakan untuk review studi literatur ini diperoleh dari salah satu sumber portal yaitu Google Scholar. Cari jurnal menggunakan kata kunci; "Stres Kerja", "Stres Kerja", "Petugas Polisi", "Stres Kerja Petugas Polisi." "Diperoleh lima jurnal kuantitatif $(N=5)$ yang mencakup semua kriteria. Berdasarkan penelaahan terhadap kelima jurnal tersebut diketahui bahwa terdapat berbagai faktor yang dapat mempengaruhi adanya stres kerja yaitu perbedaan karakteristik masing-masing individu, kemampuan individu untuk menghadapi masalah, mengatasi stres, ambiguitas peran, konflik peran, kelebihan peran, paparan insiden kritis, diskriminasi di tempat kerja, kurangnya kerja sama di antara rekan kerja, dan ketidakpuasan kerja, keadilan organisasi (di tempat kerja, kurangnya kualitas tidur, kurangnya motivasi atau dukungan dari luar, trauma masa lalu dan kekuatan psikologis yang rendah atau kontrol stres yang mempengaruhi koping yang digunakan.
\end{abstract}

Kata kunci: Petugas polisi; Stres kerja; Stres pekerjaan

\begin{abstract}
ABTRACT
Police officers are vulnerable to experience work stress, whatever the field or function they perform. The purpose of this literature study is to determine the factors that influence work stress on police officers. The journals used for review of this literature study were obtained from one portal sources, namely Google Scholar. Search journals using keywords; "Work Stress," "Job Stress," "Police officers," "Work Stress Police Officers." "Obtained five quantitative journals $(\mathrm{N}=5)$ covering all criteria. Based on a review of the five journals, it is known that there are various factors that can influence the existence of work stress namely differences in the characteristics of each individual, the ability of individuals to deal with a problem, coping stress, role ambiguity, role conflict, role overload, exposure to critical incidents, discrimination at work, lack of cooperation among coworkers, and job dissatisfaction, organizational justice (at work, lack of quality sleep, lack of motivation or support from outside, past trauma and low psychological power or stress control that affect the coping used.
\end{abstract}

Keywords: Job Stress; Police officers; Work stress

\footnotetext{
${ }^{1}$ Rachma Yuniar Wijayanti, Universitas Muhammadiyah Purwokerto, ryuniarw@gmail.com

2 Hanandita Belva Fauzi, Universitas Muhammadiyah Purwokerto, hananditabelvafauzi@ gmail.com
} 


\section{INTRODUCTION}

The Indonesian National Police (Polri) is one of the law enforcement institutions whose job is to realize excellent security services, upholding strong domestic law and security, and establishing proactive political synergies (Kepolisian Negara Republik Indonesia, 2015).

The main tasks of the Indonesian National Police are written in RI Law Number 2 of 2002 Article 13, namely: (1) Maintaining public security and order, (2) Enforcing the law, (3) providing protection, protection and services to the public. MPR RI Regulation No. VII / MPR / 2000 article 6 regarding the role of the National Police are: (1) The National Police of the Republic of Indonesia is a state instrument that plays a role in maintaining public order and security, enforcing the law, providing shelter and community services and community services, (2) In carrying out its role the Police The Republic of Indonesia must have expertise and professional skills.

The police profession, by almost all researchers, is categorized as a type of job that is very stress-prone (Ahmad, 2004). Stress experienced by the Police can come from physical, social, psychological, political and economic, it can also be stressors a work stressor such as excessive workload, low salary, lack of facilities, non-conducive work environment, risk of life while on duty, work routines and so on (Hatta \& Noor, 2007).

Members of the Police are prone to experience work stress whatever the field or function it carries out. Work stress on the Police can be triggered by many things, some of which are work and task factors, family factors, and, more importantly, economic factors. In terms of working hours, Police usually have working hours of up to 24 hours and exceed the standard working hours of 8 hours per day (Putra \& Mulyadi, 2010). In addition, workers who work on the shift night tend to experience higher work stress compared to workers who do work on the shift morning (Firmana \& Hariyono, 2011). This shows those police officers who work late into the night have a tendency to experience high work stress.

Viewed from the family factor, police officers are judged to lack time quality to spend their activities with family. Meanwhile, in terms of income or salary, police officers are said to get a salary that is classified as sufficient, but this income factor can be a very risky thing when the duties of police officers are able to threaten their mental and physical health (Putra $\&$ Mulyadi, 2010). The consequences caused by stress work experienced by members of the police force can result in events that violate the police code of ethics. Based on data obtained from the Public Relations Center of Communication and Information Polda Metro Jaya, the consequences of work stress on police members include alcoholism, suicide, and even murder of others (Putra \& Mulyadi, 2010).

Work stress is a human reaction to external stimuli; both social, occupational, environmental, and psychological factors which are considered threats. Work stress includes an emotional assessment of the perceived difference between the job demands of work with a person's ability to carry out the demands of the job (Mamonto et al., 2013). Work stress is an unpleasant situation that interferes with the performance of tasks and individual performance created due to all demands, changes, and burdens that exist in a job (Rahardjo, 2005).

Based on the facts and results of research on work stress, it can be seen that the onset of work stress in an institution or organization can result in work productivity being not optimal 
even decreased (Naqvi et al., 2013). This makes the researcher interested to explore further about the factors that influence work stress on police officers. Researchers will present a journal review related to factors that influence work stress and are expected to be of concern to all groups so that it raises early intervention.

\section{METHODS}

This literature study presents facts and problems regarding the factors that influence the work stress of police officers. Researchers searched related research topics in various journal portals through the internet, both national and international portals, which were published in the last 15 years (2004-2019). Electronic databases used are Google Scholar, Proquest, Ebsco, and Cambridge University Press.

Each article is selected based on the theme of the factors that affect the work stress of police officers. Keywords that are used as a reference when searching the journal, namely: (1) Work Stress (2) Job Stress, (3) Police Officers. Some of the titles tried by the author in the search for review sources are: "Work Stress Police Officers." The data obtained were then sorted again to adjust to the theme of this study literature. Researchers begin to look at the contents of the abstract, then look for problems raised in the forewarning, then look at the results and conclusions. Information that does not fit the theme will be eliminated by the author. The corresponding journal with the theme but not sufficient quantitative research quality criteria, then simply taken important information related to the theme and the data is used as additional information in the introductory chapter.

Search results from various portals and various keywords produce five quantitative journals $(\mathrm{N}=5)$, which will be reviewed further by the researcher. The journal was obtained from one portal sources, Google Scholar. The five journals can be downloaded in full-text on the portal.

\section{RESULTS}

The five journals reviewed in this literature study have met the criteria inclusion and are in accordance with the research theme, namely the factors that influence the work stress of police officers. There were no gender restrictions in the study sample, so the entire sample consisted of women and men. Of the five journals reviewed, each included general information in the form of titles, authors, journals and volumes, samples and settings, instruments, and results. The information will be listed in table 1 below.

Tabel 1.

Summary of Journal Review

\begin{tabular}{lll}
\hline No & Title & Result \\
\hline 1. & Where does work stress come from? & The results of this study indicate that work \\
A generalizability analysis of stress & stress is influenced by differences in the \\
in police officers. Lucas, Todd., characteristics of each individual, the & individual's ability to deal with a problem, \\
weidner, Natha., Janisse, James & indider, \\
(2012). Psychology \& Health. 27 coping with stress. &
\end{tabular}


RACHMA YUNIAR WIJAYANTI \& HANANDITA BELVA FAUZI, Faktor-Faktor yang Mempengaruhi Stres Kerja Petugas Polisi: Tinjauan Sistematis

\section{(12), 1426-1447}

2. Examining Police Officer Work Role ambiguity, role conflict, and role excess Stress Using the Job Demands- are the biggest factors that influence higher Resources Model. Frank, James., work stress on police officers.

Lambert, Eric .G., Qureshi, Hanif (2017) Journal of Contemporary Justice, 1-20.

3. Mental, Physical, and Behavioral Exposure to critical incidents, discrimination Outcomes Associated With at work, lack of cooperation among Perceived Work Stress in Police coworkers, and

Officers. Gershon, Robyn R.M., job dissatisfaction, organizational justice (at Barocas, Briana., Canton, Alisson work) correlates significantly with perceived N., Li, Xianbin., Vlahov, David work stress.

(2009). Criminal Justice and Behavior. 36(3), 275-289.

4. Stress Appraisal, Coping, And 1. The main reason for the police experience Work Engagement Among

Police Recruits: An Exploratory

Study 1,2

Mariana Kaiseler

Institute For Sport, Physical 2. Psychological power and control for the Activity And

Leisure, Leeds Metropolitan he experiences to be severe.

University, $U k$

Fernando Passos

Polícia De Segurança

Pública Lisboa, Portugal

Cristina Queirós

Universidade Do Porto,

Porto, Portugal

Pedro Sousa

Escola Prática De Polícia

Torres Novas, Portugal

Psychological Reports:

Employment Psychology \& Marketing, 214-114-2-635-646

5. A prospective study of predictors of The most significant factor affecting the stress depression symptoms in police of police officers is past trauma, this study Zhen Wang, S. Inslicht, Thomas J. found that this occurred during the first year Metzler, Clare Henn-Haase, of work. Other factors followed include Shannon E. McCaslin, greater demands on work and lower selfHuiqi Tong, Thomas C. Neylan, esteem during training and an initial Charles R. Marmar. Psychiatry Research 175 (2010) while on duty. 211-216 perception that he will experience work stress

The journal by Lucas, Weidner, \& Janisse (2012 )uses Likert-type scale instruments ranging from 1 (strongly disagree) to 6 (strongly agree) specifically designed to identify sources of stress in police work. 
Data analysis in the journal Lucas et al. (2012) was performed using the variance component procedure in SPSS Version 17.0, and the maximum likelihood estimate was limited. Both these programs and estimation methods Both are commonly used to decompose univariate variances. Conceptually, the primary and secondary assessment ratings were respectively analyzed in part with 115 (Officers) 60 (Stressors) 2 (Items) 10 (Subset) designs experimental, with stressors and items consisting of repetitive size factors and officers and subset functioned as intermediate factors participants.

The results show that work stress on police officers is influenced by differences in the characteristics of each individual, the ability of individuals to deal with problems, and coping with stress. Characteristics and abilities of individuals in dealing with a problem are related to the personality of the individual itself, namely the personality of hardiness. Individuals with hardiness low often assume a lot of things in the job as a threat and a source of stress, so when he felt work stress, the negative consequences he must face become more severe (Rahardjo, 2005).

Kaur et al (2013) research results show that coping is most often used, namely social support, self-acceptance and problem solving. Positive coping has been proven to have an effect that can reduce stress. This can help people to recognize their maladaptive treatment methods, educate them about mental damage caused by stress and at the same time, encourage them to use good coping skills such as yoga / meditation, exercise, seek support from friends / family, assess and solving problems realistically, and using acceptance and prayer will greatly help reduce psychological stress.

Frank, Lambert, \& Qureshi (2017) journal have conducted a survey of 827 police officers to determine the impact of five job demands and four job resources that cause work stress. Statistical tests descriptive for the research variables, there are significant variations in the variables dependent and independent (ie, there are no constants).

The result is that among personal characteristics, age, rank, level of education, and district/city have a significant correlation statistically with work stress. The results of this study are in line with research conducted by Fitri (2013) namely there is a relationship between age and work stress. Workers who have a longer life are more vulnerable to work stress. Older workers have more work experience with a relatively young age. This is supported by research conducted by Sadeghi \& Sa'adatpourvahid (2016) which states that age contributes to stress levels and symptoms.

Research studies conducted by Jiang et al (2018) find that there are statistically significant differences between individuals with lower levels of education and individuals who have higher levels of education that are related to the role of work, individual pressure, and resources owned by individuals itself. This is because individuals with higher levels of education have higher self-needs and higher community expectations. When their work does not meet expectations, it will cause a decrease in job satisfaction and increase the pressure associated with their work.

Gender and years of service have insignificant correlations. This is in line with research conducted by O'Neill \& Davis (2011) that there is no significant effect between gender and work stress. The variable work demands for role conflict, role ambiguity, excessive role, and fear of victimization all have a significant positive correlation with work stress, which means an increase in each independent variable is associated with an increase in the dependent variable. The role that lacks a correlation insignificant with stress from work. Job demands 


\section{RACHMA YUNIAR WIJAYANTI \& HANANDITA BELVA FAUZI, Faktor-Faktor yang Mempengaruhi Stres Kerja Petugas Polisi: Tinjauan Sistematis}

are factors related to work one's and can put pressure on people if the demands of the task are felt to be excessive. Police officers who are exposed to the daily demands of the job are more susceptible to stress and burnout (Chu, 2015; Houdmont, 2017; Veniga \& Spradley, 1981).

The role of the individual in the organization is the perception of the respondent regarding his ability to carry out the task. This relates to how employees work in accordance with their role in carrying their out duties in accordance with existing rules and in accordance with what is expected by their superiors.

Work pressure that comes from the work environment and outside the work environment can cause stress. Activities related to organizational life can make people experience stress when the individual is confronted with events that trigger the emergence of pressure and demands (Sunarni, 2007). The inability of individuals to deal with demands can be a trigger for the onset of work stress.

The journal Gershon, Barocas, Canton, Xianbin Li, \& Vlahov (2009) used a questionnaire instrument distributed to 1,072 police officers. Factor analysis was applied to all new scales, and all scales underwent correlation procedures, including Cronbach's alpha. Of the five stressors subconstruction on the police, exposure to critical incidents $(\mathrm{M}=2.00$, $\mathrm{SD}=0.44$, possible score range $=1$ to $3, \alpha=0.79)$ and job dissatisfaction $(\mathrm{M}=3.35, \mathrm{SD}=$ 0.54 , possible score range $=1$ to $5, \alpha=.36$ ) has the highest score, followed by perceptions ofinjustice organizational $(\mathrm{M}=3.22, \mathrm{SD}=0.67$, possible score range $=1$ to $5, \alpha=.39$ ) (e.g., "administration does not support officers with problems"), discrimination $(\mathrm{M}=3.16 \mathrm{SD}=$ 0.66 , possible score range $=1$ to $5, \alpha=0.44)$, and lack of cooperation and trust $(\mathrm{M}=2.40, \mathrm{SD}$ $=0.80$, range possible score $=1$ to $5, \alpha=.55$ ).

The result is that exposure to critical incidents, discrimination at work, lack of cooperation among co-workers, and job dissatisfaction and organizational injustice (at work) correlate significantly with perceived work stress. Good working relationships and interactions with peers, subordinates, and superiors are important aspects of organizational life that can help employees achieve their personal goals and organizational goals. If the relationship deteriorates, it certainly can cause stress. Interpersonal relationships can also be a source or may even be social support that helps employees cope with stressors.

Different things are explained that the sources of stress in the police can be classified into two general categories arising from "job content" which includes work schedules, work shifts, long work hours, overtime work, courts, and traumatic events and threats to physical and psychological health; and arising from "work contexts" are also called organizational stressors, which refer to organizational characteristics and behaviors of people who produce stress (for example: bureaucracy and colleague relations) (Shane, 2010).

In addition, organizational stressors that include organizational arrangements or designs (for example: management autonomy, participation, participation in decision making, etc.) may be a greater source of stress for police officers because they are related to daily routines (Violanti, 2014). Recent research on police officers shows two stressors in certain organizations namely "fellow officers not doing their work" and having "inadequate or poor quality equipment" occurring (Violanti et al., 2016).

A meta-analysis that explains stressors such as work-family conflict, job insecurity, high job demands, low job control, and social support needs, struggles with poor physical health, poor mental health, and morbidity diagnosed by doctors (Goh, J., Pfeffer, J. and 
Zenios, 2015). Women's police duties may be taken more into account by stressors related to work and work-family conflict issues than male officers. Initially, female officers had an increasing percentage in the United States, namely $11.6 \%$ in 2013, crime in the United States in 2013 the percentage increased to reach $7.4 \%$ in non-metropolitan state institutions. Female officers correct unique stressors including asking about their abilities and skills to carry out their duties, sexual harassment, release, support in police agencies, and resolve work-family conflicts (Ma et al., 2014).

He, Zhao, \& Archibold (2002) stated that in general, police officers occupy a position where they interact directly with the community and are confronted with the most elements of society threatening, antisocial and untrustworthy. These are people who break the law and take actions that endanger others. For example, killers, terrorists, or mobs who rampage. Interacting directly with the community makes the Police vulnerable to stress. stressors other that are more specific to members of the Police, such as physical hazards and the possibility of exposure to disturbances, even horrific events. The death or injury of a co-worker while on duty is known to be very stressful for officers (Finn \& Tomz, 1997; Gershon, Lin, \& Li, 2002; Jermier, Gaines, \& McIntosh,1989; Violanti, \& Aron, 1994 ). Over time, responses to or threats of terrorism are seen as important causes of police stress (Dowling, Moynihan, Genet, \& Lewis, 2006; Paton, and Violanti, 1997; Paton, D., \& Smith, 1996). The effects of routine police stress, along with exposure to critical incidents or traumatic stress, can cause physiological, psychological, and/or problems behavioral. Among the many tense experiences involving police officers in their work, the presentation of traumatic events (for example: violence, seeing a corpse, abused child, etc.) can produce some results in increased stress (Korre et al., 2014).

Exposure to human suffering and death can produce negative views about life and impact on psychological effects such as post-traumatic stress disorder (PTSD) (American Psychiatric Association, 2013), depression, and suicidal ideation (McCanlies et al., 2014, Ketch et al., 2012, Violanti et al., 2009, Ma et al., 2014). The relationship between traumatic events and the quality and quantity of sleep was examined among police officers in the Cardio-Metabolic Police Stress Police Stress study (Bond et al., 2013). In men, when assigned to "shoot the perpetrators of crime" it causes decreased sleep quality and results in sleep disturbance. Whereas in women, when seeing more "abused children" it causes worse sleep quality, increased frequency of "seeing victims of serious traffic accidents" is associated with shorter sleep duration, and increased frequency of "seeing dead bodies "was associated with poor sleep quality and shorter sleep duration.

The journal Kaiseler, QueiróS, Passos, \& Sousa (2014) explains that the effect of stress assessment due to work demands and coping at the level of work engagement (absorption, enthusiasm, and dedication) police officers support the prediction of their involvement with perceived stressor control, but not the intensity of stress experienced more than the stressor of his own choosing. Police officers reported that the absorption, enthusiasm, and dedication higher became the control of the coming stressors.

Responses are recorded on a Likert scale with anchor response 1: Not at all stressful and 5: Very stressful, or 1: No control at all and 5: Full control. After completing the stress assessment, participants then completed the COPE Brief (Carver, 1997), which was translated and adapted into Portuguese by Pais-Ribeiro \& Rodriques (2004). the brief COPE asks participants to indicate how much they used certain coping strategies during stress, and included 14strategies coping with two items representing each subscale. In this test, it was noted that Cronbach's $\alpha$ values ranged between 0.63 and 0.94 , similar to those originally 
presented by Carver (1997). In addition, fourteen coping strategies explained $83.9 \%$ of the total variance among the study data, whereas for Carver (1997) they explained $72.4 \%$ and for Pais-Ribeiro \& Rodrigues (2004) they explained 67.5\%. So it can be concluded that higher involvement among police officers is predicted by using more coping strategy approaches including coping that focuses on Problems $(\beta=0.27)$, Seeks social support $(\beta=0.05)$, and Switch to religion $(\beta=0.07)$. This shows that what is the main cause of police officers experiencing stress is the amount of physical pressure during training and mental testing and the lack of external support. Psychological power and control for stressors individuals are low, causing the stress they experience to be severe.

The results of this study indicate that stress assessment and ways to deal with it are important variables that influence work engagement among police officers, so that it can be seen that the main factor causing stress is from a demand that demands it. These findings suggest that future applied interventions encouraging work engagement among Police must strengthen perceptions of control over stressors as well as coping strategies active. After the police report related to their main assessment of the a stressor that is by showing how much stress caused by the demands, while their secondary assessment is by showing how much control they feel over the stressor.

The strength of this journal is that it conducts exploratory research studies so that researchers have the right strategy, and that supports the success of the Police in controlling work stress. Meanwhile, the drawback is that researchers pay less attention to generalizing their findings, and the assessment process is not always based on the construct. Journal Wang et al. (2010) explained that the most significant factor influencing police stress is past trauma, this study found that this occurred during the first year of work. Other factors include demands on work followed greater and lower self-esteem during training and an initial perception that he will experience work stress while on duty.

For the factors that most influence work stress, namely past trauma, researchers use the Early Trauma Inventory Self Report - Short Form instrument (ETISR-SF, Bremner et al., 2007), while The Symptom Checklist-90 - Revised (SCL) -90-R, Derogatis, 1983) is used to reveal levels of depression. Both of these will go hand in hand with the growing demands of work that are not matched by high self-esteem. At the 12-month follow-up assessment, $77.3 \%$ of participants reported symptoms of depression. The most frequent symptoms were changes in sleep quality, (56.3\%), loss energy(39.5\%) and fatigue / exhaustion (39.5\%). Different measures of depression were used for the baseline (SCL-90 R) and follow-up assessment (BDI-II) in our analysis. However, we examined the relationship between scores on the SCL scale -90-R depression at 12 months and scores on BDI-II at 12 months, and found them to be highly correlated $(r=0.77)$. Therefore, researchers focus on the discussion of what factors can cause stress.

The strength of this journal is that the researchers' findings have implications for the prevention of depressive symptoms among police officers, so researchers have determined variables to screen or identify those who might be more susceptible to depression and might benefit from endurance development interventions during academy training.attention Additional to routine work stress management during police services, including building unit cohesion by resolving conflicts, providing equipment reliable, limiting overtime work, fostering community relations, and refuting diverse workforce, holding promises to protect against the development of depression. While the shortcomings of this journal are the results of research that can be said to be insignificant with the actual situation, namely symptoms of 
low depression occur starting in the first year of work, whereas in reality, the symptoms of low depression shown by officers police are starting in the sixth month of work. So there is a possibility of error in the survey approach chosen by the researcher, which is an approach cross-sectional, which is not quite right.

\section{CONCLUSION}

From the five research reviews above, it appears that there are facts about the factors that can cause work stress on police officers. There are various kinds of behaviors that appear and various kinds of problems that arise due to work stress. The higher a person experiences work stress, it will affect the productivity of his performance. Factors that affect work stress such as differences in the characteristics of each individual, the ability of individuals to deal with a problem, coping with stress, role ambiguity, role conflict, role overload, exposure to incidents critical, discrimination at work, lack of cooperation among co-workers, and job dissatisfaction, organizational justice (at work) lack of quality sleep, lack of motivation or external support, past trauma and low psychological power or stress control that affects the coping used. For suggestions from further research can be done in more depth and more broadly related to factors regarding work stress that comes from other data sources.

\section{REFERENCES}

Ahmad, J. (2004, July). Menjadi Polisi dengan Hati Nurani. Majalah Empathy, 2-4.

American Psychiatric Association. (2013). Diagnostic and Statistical Manual of Mental Disorders, 5th ed. Washington, DC: American Psychiatric Publishing.

Bond, J., Hartley, T. ., Sarkisian, K., Andrew, M., Charles, L. ., Andrew, M. ., \& Violanti, J. . (2013). Association of Traumatic Police Event Exposure with Sleep Quality and Quantity in the BCOPS Study Cohort". International Journal of Emergency Mental Health, 15(4), 255-266.

Chu, D. (2015). Police Officer Stress Awareness and Management: A Handbook for Practitioners. Police Practice \& Research.

Dowling, F. G., Moynihan, G., Genet, B., \& Lewis, J. (2006). A Peer-Based Assistance Program for Officers with the New York City Police Department: Report of the Effects of Sept. 11, 2001. American Journal of Psychiatry, 163.

Firmana, A. S., \& Hariyono, W. (2011). Hubungan Shift Kerja Dengan Stres Kerja Pada Karyawan Bagian Operation Pt. Newmont Nusa Tenggara Di Kabupaten Sumbawa Barat. Jurnal Kesehatan Masyarakat (Journal of Public Health), 5(1), 41-44. https://doi.org/10.12928/kesmas.v5i1.1086

Fitri, A. M. (2013). Analisis Faktor-Faktor yang Berhubungan dengan Kejadian Stres Kerja pada Karyawan Bank. Jurnal Kesehatan Masyarakat, 2(1), 1-10.

Frank, J., Lambert, E. G., \& Qureshi, H. (2017). Examining Police Officer Work Stress Using the Job Demands-Resources Model. Journal of Contemporary Criminal Justice, 33(4), 348-367. https://doi.org/10.1177/1043986217724248 


\section{RACHMA YUNIAR WIJAYANTI \& HANANDITA BELVA FAUZI, Faktor-Faktor}

yang Mempengaruhi Stres Kerja Petugas Polisi: Tinjauan Sistematis

Gershon, R. R. M., Lin, S., \& Li, X. (2002). Work Stress in Aging Police Officers. Journal of Occupational and Environmental Medicine, 44, 160-167.

Gershon, R. R. M., Barocas, B., Canton, A. N., Xianbin Li, \& Vlahov, D. (2009). Mental, Physical, and Behavioral Outcomes Associated with Perceived Work Stress in Police Officers. Criminal Justice and Behavior, 36(3), 275-289. https://doi.org/10.1177/0093854808330015

Goh, J., Pfeffer, J. and Zenios, S. A. (2015). Workplace Stressors and Health Outcomes: Health Policy for the Workplace. Behavioral Science \& Policy, 1(1), 43-52. https://doi.org/10.1353/bsp.2015.0001

Hatta, R. H., \& Noor, H. (2007). Hubungan antara Hardiness dengan Burnout pada polisi pengendali massa (Dalmas) Polrestabes Bandung. Prosiding Psikologi, 124-129.

He, N., Zhao, J., \& Archibold, C. A. (2002). Gender and Police Stress: The Convergent and Divergent Impact of Work Environment, Work-Family Conflict, and stress coping mechanisms of Female and Male Police Officers. Policing: An International Journal of Police Strategies and Management, 24, 687-708.

Houdmont, J. (2017). Stressors in Police Work and Their Consequences. In R. Burke (Ed.), Stress in Policing: Sources, Consequences and Intervention. New York, NY: Routledge.

Jermier, M. J., Gaines, J., \& McIntosh, N. J. (1989). Reactions to Physically Dangerous Work: A Conceptual and Empirical Analysis. Journal of Organizational Behavior, 10, $15-23$.

Jiang, T., Tao, N., Shi, L., Ning, L., \& Liu, J. (2018). Associations between Occupational Stress and Demographic Characteristics in Petroleum Workers in the Xinjiang Arid Desert. Medicine (United States), 97(31), 1-6. https://doi.org/10.1097/MD.0000000000011543

Kaiseler, M., QueiróS, C., Passos, F., \& Sousa, P. (2014). Stress Appraisal, Coping, and Work Engagement Among Police Recruits: An Exploratory Study. Psychological Reports: Employement Psychology \& Marketing, 114(2), 635-646. https://doi.org/10.2466/01.16.PR0.114k21w2

Kaur, R., Chodagiri, V. K., \& Reddi, N. K. (2013). A Psychological Study of Stress, Personality and Coping in Police Personnel. Indian Journal of Psychological Medicine, 35(2), 141-147. https://doi.org/10.4103/0253-7176.116240

Kepolisian Negara Republik Indonesia, P. (2015). Visi dan Misi Polri.

Ketch, T. L. A., Violanti, J., \& Fekedulegn, D. (2012). Addictions and the Criminal Justice System, What Happens on the Other Side? Post-Traumatic Stress Symptoms and Cortisol Measures in a Police Cohort. Journal of Addictions Nursing, 23(1), 22-29. https://doi.org/10.3109/10884602.2011.645255.

Korre, M., Farioli, A., Varvarigou, V., Sato, S., \& Kales, S. N. (2014). A Survey of Stress Levels and Time Spent Across Law Enforcement Duties: Police Chief and Officer Agreement. Policing Advance Access, 8(2), 109-122. 
https://doi.org/10.1093/police/pau001.

Lucas, T., Weidner, N., \& Janisse, J. (2012). Where Does Work Stress Come From? A Generalizability Analysis of Stress in Police Officers. Psychology and Health, 27(12), 1426-1447. https://doi.org/10.1080/08870446.2012.687738

Ma, C. C., Andrew, M. E., Fekedulegn, D., Gu, J. K., Hartley, T. A., Charles, L. E., Violanti, J. M., \& Burchfiel, C. M. (2014). Shift Work and Occupational Stress in Police Officers. Safety and Health at Work, 6(1), 1-5. https://doi.org/10.1016/j.shaw.2014.10.001

Mamonto, N., Robot, F., \& Hamel, R. (2013). Hubungan Gaya Kepemimpinan Kepala Ruangan Dengan Tingkat Stres Kerja Perawat Di Ruang Rawat Inap Rsud Bitung. Jurnal Keperawatan UNSRAT, 1(1), 1-6.

McCanlies, E. ., Miller, D., Andrew, M. ., \& Wirth, O Burchfiel, C.M. Violanti, J. . (2014). Posttraumatic Stress Disorder Symptoms, Psychobiology, and Coexisting Disorders in Police Officers in Violanti, J. M. (Ed.), Dying for the Job: Police Work Exposure and Health, Charles $C$. Thomas Publisher.

Naqvi, S. M. H., Khan, M. A., Kant, A. Q., \& Khan, S. N. (2013). Job Stress and Employees' Productivity: Case of Azad Kashmir Public Health Sector. Interdisciplinary Journal Of Contemporary Research In Business, 5(3), 525-542.

O’Neill, J. W., \& Davis, K. (2011). Work Stress and Well-Being in the Hotel Industry. International Journal of Hospitality Management, 30(2), 385-390. https://doi.org/10.1016/j.ijhm.2010.07.007

Paton, D., \& Smith, L. M. (1996). Psychological trauma in critical occupations: Methodological and assessment strategies. In D. Paton \& J. M. Violanti (Eds.), Traumatic stress in critical occupations: Recognition, consequences, and treatment.

Paton, D. \& Violanti, J. (1997). Long Term Exposure to Traumatic Demands in Police Officers: Behavioural Addiction and Its Management. In G. Habermann (ed.), Looking Back, Moving Forward: Fifty Years of New Zealand Psychology. Psychological Society.

Putra, Y. S., \& Mulyadi, H. (2010). Pengaruh Faktor Job Demand Terhadap Kinerja Dengan Burnout Sebagai Variabel Moderating Pada Karyawan Bagian Produksi Pt.Tripilar Betonmas Salatiga. Among Makarti, Vol.3(6), 47-68.

Rahardjo, W. (2005). Kontribusi Hardiness dan Self Efficacy Terhadap Stres Kerja (Studi Pada Perawat RSUP Dr. Soeradji Tirtonegoro Klaten). Jurnal Psikologi, 47-57.

Sadeghi, K., \& Sa'adatpourvahid, M. (2016). EFL Teachers' Stress and Job Satisfaction: What Contribution Can Teacher Education Make? Iranian Journal of Language Teaching Research, 4(3), 75-96.

Shane, J. M. (2010). Organizational Stressors and Police Performance. Journal of Criminal Justice, 38(4), 807-818. https://doi.org/10.1016/j.jcrimjus.2010.05.008

Sunarni, T. dan V. I. (2007). Pengaruh Stres Kerja dan Motivasi Kerja Terhadap Kinerja Karyawan Di PT. Interbis Sejahtera Palembang. Jurnal Teknik Industri, 7(2), 7-9. 
RACHMA YUNIAR WIJAYANTI \& HANANDITA BELVA FAUZI, Faktor-Faktor yang Mempengaruhi Stres Kerja Petugas Polisi: Tinjauan Sistematis

Veniga, R., \& Spradley, J. (1981). The Work/Stress Connection. Little, Brown.

Violanti, J. M., \& Aron, F. (1994). Ranking Police Stressors. Psychological Reports.

Violanti, J.M. (2014). Dying for the Job: Police Work, Exposure and Health. Publisher Ltd, Springfield, IL.

Violanti, J.M, Slaven, J., Charles, L. M., Hartley, T., \& Burchfiel, C. (2009). Study of Shift Work and Depression in Police Officers. American Journal of Epidemiology, 169.

Violanti, John M, Fekedulegn, D., Hartley, T. A., Charles, L. E., Andrew, M. E., Ma, C. C., \& Burchfiel, C. M. (2016). Highly Rated and Most Frequent Stressors among Police Officers: Gender Differences. American Journal of Criminal Justice, 41(4), 645-662. https://doi.org/10.1007/s12103-016-9342

Wang, Z., Inslicht, S. S., Metzler, T. J., Henn-Haase, C., McCaslin, S. E., Tong, H., Neylan, T. C., \& Marmar, C. R. (2010). A Prospective Study of Predictors of Depression Symptoms in Police. Psychiatry Research, 175(3), 211-216. https://doi.org/10.1016/j.psychres.2008.11.010. 